\title{
Earthworm Uptake Routes and Rates of lonic Zn and ZnO Nanoparticles at Realistic Concentrations, Traced Using Stable Isotope Labeling
}

\author{
Adam Laycock, ${ }^{*},, \ddagger$ Maria Diez-Ortiz, ${ }^{\dagger, \infty}$ Fiona Larner, ${ }^{\S, \perp}$ Agnieszka Dybowska, ${ }^{\ddagger}$ David Spurgeon, ${ }^{\dagger}$
} Eugenia Valsami-Jones, ${ }^{\text {聿 }}$ Mark Rehkämper, ${ }^{\S, 末}$ and Claus Svendsen ${ }^{\dagger}$

${ }^{\S}$ Department of Earth Science \& Engineering, Imperial College London, London SW7 2AZ, England

"Earth Sciences, Natural History Museum, Cromwell Road, London SW7 5BD, England

${ }^{\dagger}$ Centre for Ecology and Hydrology, Wallingford, Oxfordshire OX10 8BB, England

${ }^{\infty}$ Leitat Technology Centre, C/de la Innovació 2, 08225 Terrassa, Barcelona, Spain

${ }^{\perp}$ Department of Earth Sciences, University of Oxford, South Parks Road, Oxford OX1 3AN, England

${ }^{\#}$ School of Geography, Earth and Environmental Sciences, University of Birmingham, Edgbaston, Birmingham, B15 2TT, England

Supporting Information

ABSTRACT: The environmental behavior of $\mathrm{ZnO}$ nanoparticles (NPs), their availability to, uptake pathways by, and biokinetics in the earthworm Lumbricus rubellus were investigated using stable isotope labeling. Zinc isotopically enriched to $99.5 \%$ in ${ }^{68} \mathrm{Zn}\left({ }^{68} \mathrm{Zn}\right.$ E) was used to prepare ${ }^{68} \mathrm{ZnO}$ NPs and a dissolved phase of ${ }^{68} \mathrm{Zn}$ for comparison. These materials enabled tracing of environmentally relevant (below background) NP additions to soil of only $5 \mathrm{mg}$ ${ }^{68} \mathrm{Zn}-\mathrm{E} \mathrm{kg}^{-1}$. Uptake routes were isolated by introducing earthworms with sealed and unsealed mouthparts into test soils for up to $72 \mathrm{~h}$. The $\mathrm{Zn}$ isotope compositions of the soils, pore waters and earthworms were then determined using multiple collector inductively coupled plasma mass spectrometry. Detection and quantification of ${ }^{68} \mathrm{Zn}$-E in earthworm tissue was possible after only $4 \mathrm{~h}$ of dermal exposure, when the uptake of ${ }^{68} \mathrm{Zn}-\mathrm{E}$ had increased the total $\mathrm{Zn}$ tissue concentration by $0.03 \%$. The results demonstrate that at these realistic exposure concentrations there is no distinguishable difference between the uptake of the two forms of $\mathrm{Zn}$ by the earthworm L. rubellus, with the dietary pathway accounting for $\sim 95 \%$ of total uptake. This stands in contrast to comparable studies where high dosing levels were used and dermal uptake is dominant.

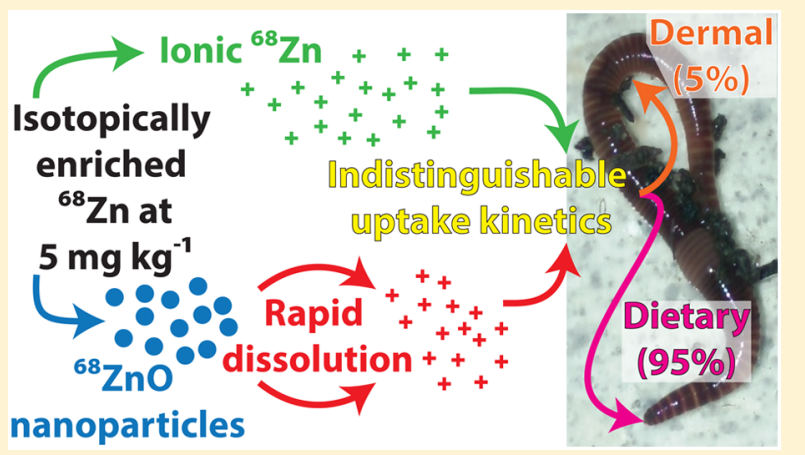

\section{INTRODUCTION}

The novel properties exhibited by engineered nanoparticles (NPs) have resulted in these materials becoming increasingly prevalent in consumer products. Zinc oxide ( $\mathrm{ZnO}$ ) NPs, for example, have found use in sunscreens, cosmetics and paints due to their UV absorbance properties. ${ }^{1,2}$ The increased manufacture and use of engineered NPs will inevitably lead to a corresponding rise in their release into natural environments. ${ }^{3}$ Engineered NPs are likely to end up in water treatment plants and be removed as part of the water treatment sludge. In places where such sludge is applied to agricultural land, it is therefore expected that soils will be a major sink. Gottschalk et al. ${ }^{4}$ determined predicted environmental concentrations (PECs) for $\mathrm{ZnO} \mathrm{NPs}$ in European sewage treatment plant sludge of $17.1 \mathrm{mg} \mathrm{kg}^{-1}$, resulting in annual fluxes of $3.25 \mu \mathrm{g} \mathrm{kg}^{-1}$ to sludge treated soils. For sewage treatment sludge and sludge treated soils Boxall et al. ${ }^{5}$ modeled PECs of $2.2-22 \mathrm{mg} \mathrm{kg}^{-1}$ and $3.2-32 \mathrm{mg} \mathrm{kg}^{-1}$, respectively, assuming between $10 \%$ and $100 \%$ market penetration for $\mathrm{ZnO}$ NPs in sunscreens (Figure
S1). These PECs are most likely to be overestimates, as recent work has demonstrated that once $\mathrm{ZnO}$ NPs enter natural systems they are subject to rapid dissolution or changes in speciation such that they are unlikely to persist.

The natural $\mathrm{Zn}$ concentrations of soils are typically much higher than the PECs. A report by the US Geological Survey found $\mathrm{Zn}$ concentrations of between 10 and $113 \mathrm{mg} \mathrm{kg}^{-1}$ for 38 rural organic rich soils, away from sources of pollution and fertilizer use. ${ }^{8}$ A comparable study of British soils from a variety of land classes identified a similar range of $\mathrm{Zn}$ levels, with values of 2.5 to $2120 \mathrm{mg} \mathrm{kg}^{-1}$. Taken together, these data imply that the $\mathrm{Zn}$ concentrations originating from $\mathrm{ZnO} \mathrm{NPs}$ in sewage treated soils are likely to be significantly lower than the natural $\mathrm{Zn}$ background levels, by a factor of 10 or more (Figure S1).

Received: July 14, 2015

Revised: October 29, 2015

Accepted: November 20, 2015

Published: November 20, 2015 
Despite this, the unknown behavior and interactions of these materials in the environment has prompted investigations to determine if NPs pose a risk.

A number of such studies have demonstrated that dissolved $\mathrm{Zn}$ has a greater toxicity than $\mathrm{ZnO}$ NPs even though higher $\mathrm{Zn}$ body burdens are commonly observed in exposures to NPs. It has thus been proposed that the release of $\mathrm{Zn}$ ions from the dissolution of $\mathrm{ZnO}$ NPs is responsible for any toxicity and that "nanospecific" toxic effects are absent. ${ }^{10-12}$ Furthermore, Hooper et al. ${ }^{10}$ suggested that conservative risk assessments for $\mathrm{ZnO}$ NPs may be conducted by assuming that all $\mathrm{Zn}$ from NPs is available in dissolved form. In contrast, other investigations presented evidence for "nanospecific" effects and demonstrated that $\mathrm{ZnO}$ NPs exerted greater toxicity for some species than equivalent doses of dissolved $\mathrm{Zn} .{ }^{13,14} \mathrm{~A}$ proposed mechanism for the observed toxicity is the production of reactive oxygen species as a consequence of the high surface area of the NPs and exposure to UV radiation from sunlight. ${ }^{13,15}$ Such effects may not be significant for organisms that live in soil, however, due to the shallow penetration depth of UV radiation. ${ }^{16}$

Notably, previous soil exposures with $\mathrm{ZnO}$ NPs were performed at $\mathrm{Zn}$ concentrations of 100 to $6400 \mathrm{mg} \mathrm{kg}^{-1}$ and these exposure levels by far exceed the PECs and, in most cases, the natural $\mathrm{Zn}$ background contents of the soils (Figure S1). High dosing levels are commonly employed in such studies, to ensure that exposed organisms develop readily resolvable increases in $\mathrm{Zn}$ concentration relative to a control, thereby enabling tracing of the $\mathrm{Zn}$ uptake from the introduced material. ${ }^{10,13}$ However, the general environmental relevance of studies conducted at such high exposure concentrations has been questioned repeatedly. ${ }^{17,18}$ Furthermore, the toxicity of metals in soils is not correlated to the exposure concentration alone, but also to bioavailability. The latter is highly dependent on the elemental form and soil properties, which will influence the uptake pathway by an organism. It is, therefore, important to investigate the bioavailability and uptake kinetics of $\mathrm{ZnO}$ NPs at environmentally realistic concentrations and to constrain the route by which they enter the body.

In this study, we investigate, over $72 \mathrm{~h}$, the uptake of $\mathrm{Zn}$ by the earthworm Lumbricus rubellus from soils dosed with $\mathrm{ZnO}$ $\mathrm{NPs}$ and soluble $\mathrm{ZnCl}_{2}$ at an environmentally relevant $\mathrm{Zn}$ level of $5 \mathrm{mg} \mathrm{kg}^{-1}$. Zinc is expected to enter the earthworms via two main pathways and both were monitored: (i) dermal uptake by direct contact with soil pore water, whereby it has been shown that considerable exchange of water occurs across the body wall ${ }^{19}$ and (ii) dietary uptake of dissolved $\mathrm{Zn}$ and NPs adsorbed to soil particles, from the earthworm's burrowing behavior and digestion of organic soil constituents. Given the low $\mathrm{Zn}$ dosing level (below background) and short exposure period ( $\leq 72 \mathrm{~h}$ ) employed here, DNA damage and genotoxic effects are not expected and were not investigated. This conclusion is supported by $\mathrm{Hu}$ et al. $^{13}$ who found that $\mathrm{ZnO} \mathrm{NP}$ soil concentrations of more than $1 \mathrm{~g} \mathrm{~kg}^{-1}$ were needed to induce DNA damage during a 7-day exposure with the earthworm Eisenia fetida.

Given the low and environmentally realistic exposure levels employed in this study, it is expected that $\mathrm{ZnO}$ NPs will undergo rapid dissolution without inhibition by the saturated pore waters that were likely encountered in a recent and comparable investigation, which employed much higher dosing levels. $^{12}$ A comparative exposure with dissolved $\mathrm{Zn}$ was included in our experimental program to further test this hypothesis. If rapid dissolution of $\mathrm{ZnO}$ NPs occurs, this should produce similar exposure scenarios for the soils dosed with nanoparticulate and dissolved $\mathrm{Zn}$ and, therefore, comparable uptake is expected. The tracing and quantification of the dosed $\mathrm{Zn}$ at the low employed exposure levels was made possible by the use of stable isotope labeling in conjunction with high precision isotope ratio analysis by multiple collector inductively coupled plasma mass spectrometry (MC-ICP-MS). ${ }^{20}$ While such techniques were previously applied in aquatic exposures, $^{21,22}$ this investigation represents the first application of stable isotope tracing methods to study the fate of engineered nanomaterials in soils.

\section{METHODS}

2.1. Materials and Reagents. The well characterized, loamy sand standard test soil LUFA-Speyer 2.2 (Sp 2121, Germany, 2009), with a $\mathrm{pH}$ of 5.5 , a total organic carbon content of $2.09 \%$, a cation exchange capacity of 10.0 mequiv/100 g and a water-holding capacity (WHC) of $46.5 \%$, was used as the exposure medium. The soil was oven-dried at $60{ }^{\circ} \mathrm{C}$ overnight prior to use, to eliminate undesired soil fauna.

Zinc that is artificially enriched in the ${ }^{68} \mathrm{Zn}$ isotope $\left({ }^{68} \mathrm{Zn}-\mathrm{E}\right)$ from the natural abundance of $18.8 \%$ to $99.5 \%$, was purchased as a metal powder from Isoflex USA and used for the preparation of ${ }^{68} \mathrm{ZnO}$ NPs and a ${ }^{68} \mathrm{ZnCl}_{2}$ solution, hereafter referred to as dissolved ${ }^{68} \mathrm{Zn}$. AnalaR grade concentrated $14.5 \mathrm{M} \mathrm{HNO}_{3}$ and $6 \mathrm{M} \mathrm{HCl}$ were purified by subboiling distillation in a quartz still. Trace element grade Optima $28 \mathrm{M}$ $\mathrm{HF}$ was purchased from Fisher Scientific. Milli-Q water of $>18 \mathrm{M} \Omega \mathrm{cm}$ quality (Millipore, UK) and 30\% Suprapur $\mathrm{H}_{2} \mathrm{O}_{2}$ (VWR UK) were used throughout.

The ${ }^{68} \mathrm{ZnO}$ NPs applied in this study were prepared by forced hydrolysis in diethylene glycol (DEG) and are from the same synthesis batch as those previously used by Khan et al. ${ }^{21}$ Thorough characterization of the ${ }^{68} \mathrm{ZnO}$ NPs was performed to determine the particle size and crystal structure of the material. Based on TEM image analysis the NPs have a primary particle size of $7.8 \pm 1.2 \mathrm{~nm}(n=$ 100). Full details of the preparation and characterization of the two ${ }^{68} \mathrm{Zn}$-E forms are presented in the Supporting Information.

2.2. Preparation of the Exposure Medium. Eight soil samples with $600 \mathrm{~g}$ dry weight each were prepared. This encompasses two controls and three samples each for treatment with ${ }^{68} \mathrm{ZnO}$ NPs and dissolved ${ }^{68} \mathrm{Zn}$. The latter were dosed to a ${ }^{68} \mathrm{Zn}$-E concentration of 5 $\mathrm{mg} \mathrm{kg}{ }^{-1}$ by adding $4.04 \mathrm{~mL}$ of the corresponding ${ }^{68} \mathrm{Zn}-\mathrm{E}$ stock suspension or solution. This is equivalent to the PEC, modeled by Boxall et al. $^{5}$ for sewage treated soils, assuming a $16 \%$ market penetration for $\mathrm{ZnO}$ NPs in sunscreens.

The resulting concentration of DEG in the ${ }^{68} \mathrm{ZnO}$ NP spiked soils was $7.5 \mathrm{~g} \mathrm{~kg}^{-1}$. This concentration was matched in the soils spiked with dissolved ${ }^{68} \mathrm{Zn}$ and one of the control samples by adding $4.04 \mathrm{~mL}$ of DEG. At this level, DEG is not expected to significantly alter the solubility or behavior of the ${ }^{68} \mathrm{ZnO}$ NPs once they are mixed into the test soils. This assumption is supported by recent work, ${ }^{22}$ which demonstrated that the addition of a similar $\mathrm{ZnO} \mathrm{NP}$ suspension in DEG to an aqueous exposure medium led to rapid agglomeration and dissolution of the NPs, as the stabilizing effect of DEG was soon lost. To investigate whether the presence of DEG had an observable effect on the behavior and mortality of L. rubellus, a separate one-week trial experiment was carried out prior to the main set of exposures. A report on the effects of ethylene glycol, which has a very similar molecular structure to DEG, was shown to result in $25 \%$ mortality of the earthworm Eisenia fetida when exposed at a concentration of $20 \mathrm{~g}$ $\mathrm{kg}^{-123}$

Thorough mixing of the ${ }^{68} \mathrm{Zn}-\mathrm{E}$ and DEG with a spatula, followed by the addition of water to achieve a moisture content of $27 \%(\mathrm{w} / \mathrm{w})$, corresponding to $50 \%$ of the maximum WHC, were performed to achieve a homogeneous distribution of the reagents. The soils were then left to equilibrate for 2 days prior to the introduction of earthworms. 
2.3. Test Organisms. The test organism in this study was the earthworm Lumbricus rubellus. The specimens were collected from the field (Lasebo BV, Nijkerkerveen, The Netherlands) and maintained in a laboratory culture. Worms were kept in moist soil and fed with horse manure free of any pharmaceuticals. Two days prior to exposure, adult worms with developed clitellum and wet weights ranging from 1.08 to $2.25 \mathrm{~g}$ were transferred to clean Lufa 2.2 soil at $50 \%$ of WHC for acclimatization and kept in the dark at a temperature of $12 \pm 2{ }^{\circ} \mathrm{C}$.

After 2 days acclimatization, 90 earthworms were rinsed with distilled water, blotted dry on filter paper, placed in Petri dishes lined with moist filter paper and allowed to void their guts for a further 2 days, with the filter paper being changed after $24 \mathrm{~h}$ to avoid coprophagy. For L. rubellus, egestion for $48 \mathrm{~h}$ has been shown to be sufficient for depuration. ${ }^{24}$ Six control earthworms were selected at this stage, which were used to confirm the natural $\mathrm{Zn}$ isotope composition of unexposed acclimatized earthworms. The remaining 84 individuals were split into 2 groups of 42 . One of the groups was prevented from oral ingestion so that only dermal uptake through the body wall was possible. This was achieved by removing mucus from the mouth region before sealing by dipping into medical hystacryl glue (Braun aesculap, Germany) using the method described by Vijver et al. ${ }^{25}$ The glue was allowed to dry before introducing the earthworms into the test soil.

2.4. Exposure Protocol and Sampling. After acclimatization and prior to introduction of the earthworms, representative soil samples of $\sim 2 \mathrm{~g}$ were taken and oven-dried at $60^{\circ} \mathrm{C}$ to obtain the dry weights of the samples that are needed for the determination of $\mathrm{Zn}$ concentrations. Soil pore water was collected prior to and following completion of the exposure period. To this end, $\sim 30 \mathrm{~g}$ soil aliquots from each of the eight $600 \mathrm{~g}$ treatments were placed in $50 \mathrm{~mL}$ Falcon tubes and saturated to their maximum WHC. The tubes were centrifuged (J2-HC, Beckman Coulter, California) for $90 \mathrm{~min}$ at $4000 \mathrm{~g}$ to separate the soil detritus from the pore water before pipetting the latter from the top of the tube. The pore water samples were then frozen for storage prior to analysis.

To make optimal use of the available ${ }^{68} \mathrm{ZnO}$ NPs, the biokinetic experiments were conducted in two stages over a 6-day period, whereby earthworms were sampled after 4,8 , and $24 \mathrm{~h}$ in stage 1 and after 36,48 , and $72 \mathrm{~h}$ in stage 2 . With this approach, it was possible to collect samples at twice as many sampling time points in comparison to a single stage procedure. A full outline of the exposure protocol and sample timing is given in Table S1. In the first exposure stage, three sealed and unsealed earthworms each, with a mean wet weight of 1.62 $\pm 0.21 \mathrm{~g}(1 \mathrm{sd}$; range $=1.15-2.02 \mathrm{~g})$, were added to each of the eight soil replicates, one control dosed with DEG and one nondosed control. One sealed and one unsealed earthworm were removed from the test soils dosed with ${ }^{68} \mathrm{Zn}$-E after 4, 8, and $24 \mathrm{~h}$ of exposure. The sealed and unsealed earthworms were easily distinguishable as the glue over the mouthparts of the sealed specimens was readily visible (Figure S2). Once the first exposure stage was completed, a second separate set of three sealed and three unsealed earthworms, with a mean wet weight of $1.40 \pm 0.25 \mathrm{~g}(1 \mathrm{sd}$; range $=1.11-2.21 \mathrm{~g})$ were added back into each test soil. For this second exposure set, one sealed, and one unsealed earthworm each were removed from the containers at 36,48 , and $72 \mathrm{~h}$. The earthworms exposed to the control soils were removed after $72 \mathrm{~h}$.

Throughout the 6-day exposure, the burrowing behavior and appearance of the earthworms was recorded. After sampling, the earthworms were prepared and allowed to void their guts as outlined above. None of the sealed earthworms excreted soil particles, confirming that ingestion was successfully prevented. The earthworms were snap-frozen and freeze-dried for 2 days, and then, the dried tissue was weighed.

2.5. Sample Preparation and Isotopic Analysis. The samples of soil, pore water and L. rubellus were prepared for analysis in the clean room facilities of the Imperial College MAGIC Laboratories. First a microwave digestion procedure was used to obtain sample solutions, which were processed through a one-step anion exchange column chemistry procedure for removal of the sample matrix to obtain pure $\mathrm{Zn}$ sample solutions for isotopic analysis. ${ }^{20,21,26}$ Full details of the digestion and chemical separation protocols can be found in the Supporting Information. The subsequent isotopic analyses were also conducted in the MAGIC Laboratories using a Nu Plasma HR MCICP-MS instrument, following methods outlined by Larner and Rehkämper. $^{20}$

2.6. Data Reduction. The measured diagnostic ${ }^{68} \mathrm{Zn} /{ }^{66} \mathrm{Zn}$ ratio $\left(R_{\text {meas }}\right)$ of a sample is a function of the proportion of ${ }^{68} \mathrm{Zn}$ - $\mathrm{E}$ that is present relative to the natural $\mathrm{Zn}$ background, and the degree of isotopic enrichment (for the ${ }^{68} \mathrm{Zn}-\mathrm{E}$ ). As the isotope compositions of the enriched and the natural endmember are known (Table S3), the proportion of ${ }^{68} \mathrm{Zn}$-E to total $\mathrm{Zn}\left(\mathrm{fr}_{\text {en }}\right)$ in a sample can be calculated as

$$
\mathrm{fr}_{\text {en }}=\left(\left(\frac{{ }^{68} \mathrm{Ab} \text { en }-\left(R_{\text {meas }} \times{ }^{66} \mathrm{Ab}_{\text {en }}\right)}{\left(R_{\text {meas }} \times{ }^{66} \mathrm{Ab}_{\text {nat }}\right)-{ }^{68} \mathrm{Ab}_{\text {nat }}}\right)+1\right)^{-1}
$$

Here, $\mathrm{Ab}$ with a prefix of 68 or 66 refers to the relative (molar) abundance of the corresponding isotope in ${ }^{68} \mathrm{Zn}-\mathrm{E}$ or natural $\mathrm{Zn}$, as identified by the suffix en or nat, respectively.

From eq 1 the abundance of each isotope of $\mathrm{Zn}$ in a sample can be calculated. For example, the isotopic abundance of ${ }^{66} \mathrm{Zn}$ in a sample $\left({ }^{66} \mathrm{Ab}\right.$ sam $)$ can be determined by

$$
{ }^{66} \mathrm{Ab}_{\text {sam }}=\left(\mathrm{fr}_{\mathrm{en}} \times{ }^{66} \mathrm{Ab} \mathrm{b}_{\mathrm{en}}\right)+\left(\left(1-\mathrm{fr}_{\mathrm{en}}\right) \times{ }^{66} \mathrm{Ab} \mathrm{b}_{\text {nat }}\right)
$$

In this study, the molar amount of ${ }^{66} \mathrm{Zn}$ for each sample $\left(\mathrm{N}-{ }^{66} \mathrm{Zn}_{\text {sam }}\right)$ was determined by comparing the measured ${ }^{66} \mathrm{Zn}$ ion beam intensity to a suitable calibration curve, whereby admixed $\mathrm{Cu}$ was used as internal standard. The total molar amount of $\mathrm{Zn}$ in the sample $\left(\mathrm{N}-\mathrm{Zn}_{\text {sam }}\right)$ was then calculated by dividing the molar amount of ${ }^{66} \mathrm{Zn}$ in the sample by the isotopic abundance of ${ }^{66} \mathrm{Zn}$ :

$$
\mathrm{N}-\mathrm{Zn}_{\text {sam }}={ }^{66} \mathrm{~N}-\mathrm{Zn}_{\text {sam }} /{ }^{66} \mathrm{Ab} \text { sam }
$$

The molar amounts of ${ }^{68} \mathrm{Zn}-\mathrm{E}\left(\mathrm{N}-\mathrm{Zn}_{\mathrm{en}}\right)$ and natural $\mathrm{Zn}\left(\mathrm{N}-\mathrm{Zn}_{\text {nat }}\right)$ were derived using the proportion of ${ }^{68} \mathrm{Zn}-\mathrm{E}$ in the sample (eq 1):

$$
\begin{aligned}
& \mathrm{N}-\mathrm{Zn}_{\mathrm{en}}=\mathrm{N}-\mathrm{Zn}_{\text {sam }} \times \mathrm{fr}_{\mathrm{en}} \\
& \mathrm{N}-\mathrm{Zn}_{\text {nat }}=\mathrm{N}-\mathrm{Zn}_{\text {sam }}-\left(\mathrm{N}-\mathrm{Zn}_{\text {sam }} \times \mathrm{fr}_{\mathrm{en}}\right)=\mathrm{N}-\mathrm{Zn}_{\text {sam }}-\mathrm{N}-\mathrm{Zn}_{\mathrm{en}}
\end{aligned}
$$

The mass amounts of ${ }^{68} \mathrm{Zn}-\mathrm{E}\left(\mathrm{M}-\mathrm{Zn}_{\mathrm{en}}\right)$ and natural $\mathrm{Zn}\left(\mathrm{M}-\mathrm{Zn}_{\mathrm{nat}}\right)$ in the sample were determined by multiplying the molar amount by the corresponding atomic weight of ${ }^{68} \mathrm{Zn}-\mathrm{E}\left(\mathrm{AtWt}_{\mathrm{en}}\right)$ or natural $\mathrm{Zn}$ $\left(\mathrm{AtWt}_{\mathrm{nat}}\right)$ (Table S2).

$$
\begin{aligned}
& \mathrm{M}-\mathrm{Zn}_{\mathrm{en}}=\mathrm{N}-\mathrm{Zn}_{\mathrm{en}} \times \mathrm{AtWt}_{\mathrm{en}} \\
& \mathrm{M}-\mathrm{Zn}_{\text {nat }}=\mathrm{N}-\mathrm{Zn}_{\mathrm{nat}} \times \mathrm{AtWt} \mathrm{t}_{\mathrm{nat}}
\end{aligned}
$$

To detect and quantify the presence of ${ }^{68} \mathrm{Zn}$-E in a sample, the isotopic analysis must identify an analytically resolvable deviation from the natural ${ }^{68} \mathrm{Zn} /{ }^{66} \mathrm{Zn}$ ratio. The smallest clearly resolvable isotopic deviation in ${ }^{68} \mathrm{Zn} /{ }^{66} \mathrm{Zn}$ is thereby determined by the precision of the analytical technique and the level of natural isotopic variability. The former is best defined by the between-run (external) precision of standard solution analyses, which typically featured a reproducibility of better than $\pm 0.10 \%$ o ( $2 \mathrm{sd}$ ). The latter is constrained by the data obtained for the control earthworm specimens, which provided a mean value with an uncertainty of $\pm 0.13 \%$ o ( $2 \mathrm{sd}, n=8)$. Based on error propagation, a deviation in ${ }^{68} \mathrm{Zn} /{ }^{66} \mathrm{Zn}$ (between sample and natural value) of only $0.16 \%$ is therefore analytically resolvable at the $2 \mathrm{sd}$ level. This is equivalent to an increase in the total $\mathrm{Zn}$ concentration of a sample, from the addition of ${ }^{68} \mathrm{Zn}-\mathrm{E}$, of only $0.03 \%$. For example, the control samples had natural $\mathrm{Zn}$ concentrations of between 400 and $800 \mathrm{mg} \mathrm{kg}^{-1}$ for the earthworms, $15 \mathrm{mg} \mathrm{kg}^{-1}$ for soil and $10 \mu \mathrm{g} \mathrm{L}^{-1}$ for soil pore water. To create an analytically resolvable deviation in these samples, the addition of $0.01-0.02 \mathrm{mg} \mathrm{kg}^{-1}, 0.5 \mu \mathrm{g} \mathrm{kg}^{-1}$, and $0.3 \mathrm{ng}$ $\mathrm{L}^{-1}$ of ${ }^{68} \mathrm{Zn}-\mathrm{E}$ is therefore required, respectively.

2.7. Kinetic Modeling. The rate constants for $\mathrm{Zn}$ uptake from soil $\left(k_{1}\right.$, in $\left.\mathrm{g}_{\text {soil }} \mathrm{g}_{\text {worm }}{ }^{-1} \mathrm{~h}^{-1}\right)$ and elimination $\left(k_{2}, \mathrm{~h}^{-1}\right)$ were estimated by applying a one-compartment first-order kinetic model to the data for the 72 -h uptake phase: ${ }^{27}$ 


$$
\left[{ }^{68} \mathrm{Zn}-\mathrm{E}\right]_{\text {worm }}=\left(k_{1} / k_{2}\right) \times\left[{ }^{68} \mathrm{Zn}-\mathrm{E}\right]_{\text {soil }} \times\left(1-\mathrm{e}^{-k_{2} \times t}\right)
$$

Here $\left[{ }^{68} \mathrm{Zn}-\mathrm{E}\right]_{\text {worm }}$ is the concentration of ${ }^{68} \mathrm{Zn}-\mathrm{E}$ in the earthworm tissue at a given time $\mathrm{t}$ (in hours), and $\left[{ }^{68} \mathrm{Zn}-\mathrm{E}\right]_{\text {soil }}$ is the ${ }^{68} \mathrm{Zn}-\mathrm{E}$ concentration of the dry soil. While we employ the initial ${ }^{68} \mathrm{Zn}$-E concentration of the soil for these calculations, it is reasonable to assume that this value remained essentially constant, due to the large ${ }^{68} \mathrm{Zn}$-E budget of the reservoir. For comparison, the uptake rate constant $k_{1 \text {-water }}$ (in $\mathrm{mL}_{\text {water }} \mathrm{g}_{\text {worm }}{ }^{-1} \mathrm{~h}^{-1}$ ) was determined for the sealed earthworms using the ${ }^{68} \mathrm{Zn}$-E concentration of the pore water sampled after $72 \mathrm{~h}\left(\left[{ }^{68} \mathrm{Zn}-\mathrm{E}\right]_{\text {water-72h }}\right)$ in place of $\left[{ }^{68} \mathrm{Zn}-\mathrm{E}\right]_{\text {soil }}$ (eq 8). Unlike $\left[{ }^{68} \mathrm{Zn}-\mathrm{E}\right]_{\text {soil }}$, the ${ }^{68} \mathrm{Zn}$-E concentrations of the pore waters changed during the exposure (Table S1). However, given that rapid dissolution of the ${ }^{6} \mathrm{ZnO}$ NPs was confirmed, and comparable pore water ${ }^{6} \mathrm{Zn}-\mathrm{E}$ concentrations were observed in the exposures with ${ }^{68} \mathrm{ZnO}$ NPs and dissolved ${ }^{68} \mathrm{Zn}$, the application of $\left[{ }^{68} \mathrm{Zn}-\mathrm{E}\right]_{\text {water-72h }}$ in the calculations provides a reasonable, first-order characterization of the system. The use of a longer exposure period to achieve steady state tissue burdens, or a separate elimination period to determine the elimination rate constant, would involve sealed worms suffering from starvation. Our approach was therefore deemed more suitable for the kinetic modeling.

The uptake and elimination rate constants obtained with eq 8 can be used to calculate the kinetic bioaccumulation factor, $\mathrm{BAF}_{\mathrm{k}}$, from the ratio of the uptake and elimination rate constants: ${ }^{28}$

$$
\begin{aligned}
& \mathrm{BAF}_{k-\text { soil }}=k_{1} / k_{2} \\
& \mathrm{BAF}_{k-\text { water }}=k_{1-\text { water }} / k_{2}
\end{aligned}
$$

A bioaccumulation factor can also be determined for any time point from the ratio of the ${ }^{68} \mathrm{Zn}$-E concentrations in the earthworms relative to the surrounding medium. ${ }^{28}$ Here, BAFs were calculated for the $72-\mathrm{h}$ exposure period, using the earthworm tissue burdens determined at 72 $\mathrm{h}\left(\left[{ }^{68} \mathrm{Zn}-\mathrm{E}\right]_{\text {worm }-72 \mathrm{~h}}\right)$ and the (essentially constant) ${ }^{68} \mathrm{Zn}-\mathrm{E}$ concentration of the soils or the ${ }^{68} \mathrm{Zn}$-E contents of the pore waters as measured at the $72 \mathrm{~h}$ time point:

$$
\begin{aligned}
& \mathrm{BAF}_{\text {soil-72h }}=\left[{ }^{68} \mathrm{Zn}-\mathrm{E}\right]_{\text {worm-72h }} /\left[{ }^{68} \mathrm{Zn}-\mathrm{E}\right]_{\text {soil }} \\
& \mathrm{BAF}_{\text {water-72h }}=\left[{ }^{68} \mathrm{Zn}-\mathrm{E}\right]_{\text {worm-72h }} /\left[{ }^{68} \mathrm{Zn}-\mathrm{E}\right]_{\text {water-72h }}
\end{aligned}
$$

However, BAFs are most reasonably determined from the steady state concentrations that are obtained in exposures, which are long enough to establish a full dynamic equilibrium between $\mathrm{Zn}$ uptake and elimination. The calculated uptake and elimination rate constants allowed the modeling of a 30-day exposure period to estimate steady state ${ }^{68} \mathrm{Zn}$-E tissue burdens $\left(\left[{ }^{68} \mathrm{Zn} \text {-E }\right]_{\text {worm-ss }}\right)$. The steady state BAFs can then determined from the ratio of $\left[{ }^{68} \mathrm{Zn}-\mathrm{E}\right]_{\text {worm-ss }}$ to the ${ }^{68} \mathrm{Zn}-\mathrm{E}$ concentrations of the soils or as determined for pore water after $72 \mathrm{~h}$ of exposure:

$$
\begin{aligned}
& \mathrm{BAF}_{\text {soil-ss }}=\left[{ }^{68} \mathrm{Zn}-\mathrm{E}\right]_{\text {worm-ss }} /\left[{ }^{68} \mathrm{Zn}-\mathrm{E}\right]_{\text {soil }} \\
& \mathrm{BAF}_{\text {water-ss }}=\left[{ }^{68} \mathrm{Zn}-\mathrm{E}\right]_{\text {worm-ss }} /\left[{ }^{68} \mathrm{Zn}-\mathrm{E}\right]_{\text {water-72h }}
\end{aligned}
$$

As calculations generate essentially identical results for $\mathrm{BAF}_{k-\text { soil }} \approx$ $\mathrm{BAF}_{\text {soil-ss, }}$ and $\mathrm{BAF}_{k \text {-water }} \approx \mathrm{BAF}_{\text {water-ss }}$, because these parameters are determined from the same input values, only a single result is reported in the following.

\section{RESULTS}

3.1. Soil and Pore Water. The control samples all showed ${ }^{68} \mathrm{Zn} /{ }^{66} \mathrm{Zn}$ isotope ratios that are within the expected natural variability and natural $\mathrm{Zn}$ concentrations that are comparable to the exposed samples (Tables S4 and S5). The soil samples dosed with ${ }^{68} \mathrm{ZnO} \mathrm{NP}$ and dissolved ${ }^{68} \mathrm{Zn}$ had initial measured dry weight ${ }^{68} \mathrm{Zn}$-E concentrations of $3.58 \pm 0.75$ ( $1 \mathrm{sd}, n=3$ ) and $3.51 \pm 1.13 \mathrm{mg} \mathrm{kg}^{-1}(1 \mathrm{sd}, n=3)$, respectively (Table S5). These concentrations are identical, within uncertainty, and show a recovery of $>70 \%$ for the ${ }^{68} \mathrm{Zn}$ - $\mathrm{E}$ that was added to the soils at $5 \mathrm{mg} \mathrm{kg}^{-1}$. The pore water samples collected after 2 days of acclimatization from soils spiked with ${ }^{68} \mathrm{ZnO}$ NPs and dissolved ${ }^{68} \mathrm{Zn}$, had ${ }^{68} \mathrm{Zn}$-E concentrations of $61.6 \pm 14.9$ ( $1 \mathrm{sd}$, $n=3)$ and $53.6 \pm 6.9 \mu \mathrm{g} \mathrm{L}^{-1}(1 \mathrm{sd}, n=3)$, respectively. At the end of the 6-day experiment, the pore water concentrations had increased to $96.2 \pm 6.3(1 \mathrm{sd}, n=3)$ and $119.7 \pm 0.2 \mu \mathrm{g} \mathrm{L}^{-1}(1$ sd, $n=3)$ for the ${ }^{68} \mathrm{ZnO} \mathrm{NP}$ and the dissolved ${ }^{68} \mathrm{Zn}$ exposure, respectively (Table $\mathrm{S} 1$ and Figure $\mathrm{S} 3$ ).

3.2. Earthworms. There was no mortality of earthworms over the exposure period. Furthermore, the burrowing behavior and appearance of the earthworms in the dosed soils did not differ from those observed in the nondosed and DEG-only dosed control soils, both for the 7-day pretrial and the main exposure.

Detection of ${ }^{68} \mathrm{Zn}$-E in the earthworm tissues was achieved for all exposed organisms and accurate quantification of ${ }^{68} \mathrm{Zn}-\mathrm{E}$ was possible even after only $4 \mathrm{~h}$ of dermal exposure, when the contribution of ${ }^{68} \mathrm{Zn}$-E to total $\mathrm{Zn}$ was as low as $0.03 \%$. The majority of exposed earthworms had ${ }^{68} \mathrm{Zn}-\mathrm{E}$ concentrations that were orders of magnitude above the minimum detection levels (Figure S4). In general, the samples exposed for longer periods of time displayed higher levels of ${ }^{68} \mathrm{Zn}-\mathrm{E}$ (Table S5 and Figure 1).
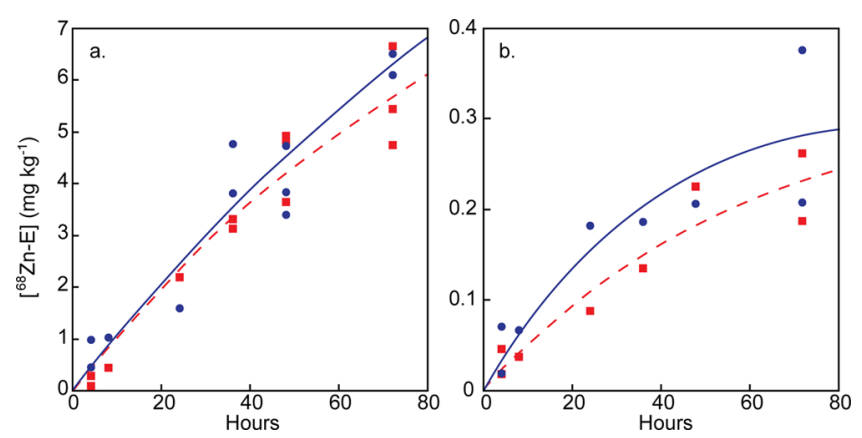

Figure 1. Enriched ${ }^{68} \mathrm{Zn}$ concentrations in earthworms exposed to ${ }^{68} \mathrm{ZnO} \mathrm{NPs}$ (red squares and dashed line) and dissolved ${ }^{68} \mathrm{Zn}$ (blue circles and solid line): (a) unsealed earthworms (dermal and oral uptake) and (b) sealed earthworms (dermal uptake only). The best-fit lines were calculated using the modeled results and the uptake and elimination rate constants given in Table 1.

Investigation of the biokinetics revealed that the uptake rate constants $k_{1}$ for ${ }^{68} \mathrm{Zn}$-E accumulation by L. rubellus from soil are an order of magnitude higher for the unsealed compared to sealed worms (Table 1) and this difference is significant based on a generalized likelihood ratio test. ${ }^{29}$ In contrast, the $k_{1}$ and $k_{1 \text {-water }}$ values determined for uptake of the two forms of ${ }^{68} \mathrm{Zn}$-E in exposures of unsealed or sealed earthworms were similar, whereby $k_{1 \text {-water }}$ is about twice as large as $k_{1}$. Furthermore, the calculated elimination rate constants were also identical, within uncertainty, for the two forms of ${ }^{68} \mathrm{Zn}-\mathrm{E}$, regardless of whether the exposed earthworms were sealed or unsealed (Table 1).

The results from the modeled 30-day exposure (Figure S5) show that for dermal-only uptake, steady state ${ }^{68} \mathrm{Zn}$-E tissue concentrations of $\sim 0.3 \mathrm{mg} \mathrm{kg}^{-1}$ are reached after approximately 1 week for exposures to both ${ }^{68} \mathrm{ZnO} \mathrm{NP}$ and dissolved ${ }^{68} \mathrm{Zn}$. A longer period of 2 to 3 weeks is required until a dynamic equilibrium is achieved for the exposures with dermal and dietary accumulation. In this case, the modeling suggests steady state ${ }^{68} \mathrm{Zn}$-E tissue concentrations of $\sim 11.5$ and $\sim 16.5 \mathrm{mg} \mathrm{kg}^{-1}$ for the ${ }^{68} \mathrm{ZnO} \mathrm{NP}$ and dissolved ${ }^{68} \mathrm{Zn}$ exposures, respectively 
Table 1. Calculated Uptake $\left(k_{1}\right.$ and $\left.k_{1-\text { water }}\right)$ and Elimination $\left(k_{2}\right)$ Rate Constants ${ }^{a}$

\begin{tabular}{|c|c|c|c|c|}
\hline & \multicolumn{2}{|c|}{ dermal-only uptake ${ }^{b}$} & \multicolumn{2}{|c|}{ dermal and oral uptake ${ }^{c}$} \\
\hline & ${ }^{68} \mathrm{ZnO} \mathrm{NPs}$ & dissolved ${ }^{68} \mathrm{Zn}$ & ${ }^{68} \mathrm{ZnO} \mathrm{NPs}$ & dissolved ${ }^{68} \mathrm{Zn}$ \\
\hline$k_{1}\left(\mathrm{~g}_{\text {soil }} \mathrm{g}_{\text {worm }}{ }^{-1} \mathrm{~h}^{-1}\right)$ & $0.0016 \pm 0.0004$ & $0.0025 \pm 0.0009$ & $0.032 \pm 0.005$ & $0.031 \pm 0.006$ \\
\hline$k_{1-\text { water }}\left(\mathrm{mL}_{\text {water }} \mathrm{g}_{\text {worm }}{ }^{-1} \mathrm{~h}^{-1}\right)$ & $0.057 \pm 0.016$ & $0.072 \pm 0.026$ & & \\
\hline$k_{2}\left(\mathrm{~h}^{-1}\right)^{d}$ & $0.016 \pm 0.011$ & $0.026 \pm 0.017$ & $0.009 \pm 0.006$ & $0.006 \pm 0.007$ \\
\hline$R^{2 d}$ & 0.917 & 0.843 & 0.946 & 0.919 \\
\hline \multicolumn{5}{|c|}{ 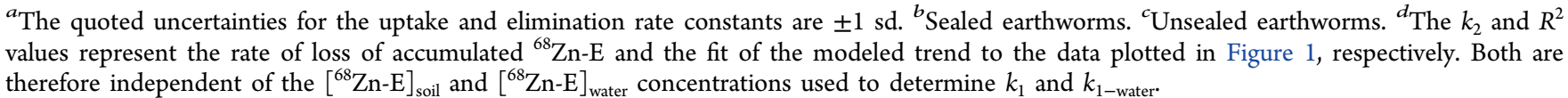 } \\
\hline
\end{tabular}

Table 2. Summary of Bioaccumulation Factors (BAF) Determined for Uptake of ${ }^{68} \mathrm{Zn}$-E by Earthworms, As Defined in Eqs 10-14

\begin{tabular}{|c|c|c|c|c|c|c|}
\hline & \multicolumn{2}{|c|}{ dermal-only uptake ${ }^{a}$} & \multicolumn{2}{|c|}{ dermal and oral uptake ${ }^{b}$} & \multicolumn{2}{|c|}{ Heggelund et al. ${ }^{11}$} \\
\hline & ${ }^{68} \mathrm{ZnO} \mathrm{NPs}$ & dissolved ${ }^{68} \mathrm{Zn}$ & ${ }^{68} \mathrm{ZnO} \mathrm{NPs}$ & dissolved ${ }^{68} \mathrm{Zn}$ & $\mathrm{ZnO} \mathrm{NPs}$ & dissolved $\mathrm{Zn}$ \\
\hline $\mathrm{BAF}_{\text {soil-72h }}$ & 0.06 & 0.08 & 1.56 & 1.53 & & \\
\hline $\mathrm{BAF}_{\text {water-72h }}$ & 2.33 & 2.20 & 58.0 & 44.76 & & \\
\hline BAF $_{\text {soil-ss }}$ & $0.10^{c}$ & $0.10^{c}$ & $3.40^{c}$ & $4.86^{c}$ & $0.48^{e}$ & $0.39^{e}$ \\
\hline $\mathrm{BAF}_{\text {water-ss }}$ & $3.68^{d}$ & $2.84^{d}$ & 126.6 & 142.2 & $77.7^{f}$ & $31.2^{f}$ \\
\hline
\end{tabular}

${ }^{a}$ Sealed earthworms. ${ }^{b}$ Unsealed earthworms. ${ }^{c} \mathrm{BAF}_{\text {soil-ss }} \approx \mathrm{BAF}_{\mathrm{k}-\text { soil }} \cdot{ }^{d} \mathrm{BAF}_{\text {water-ss }} \approx \mathrm{BAF}_{\mathrm{k} \text {-water. }}{ }^{e}$ Labeled as average $\mathrm{BAF}$ for exposures of unsealed earthworms in soil at $\mathrm{pH} 6.4$ by Heggelund et al. ${ }^{11}{ }_{\mathrm{f}}^{\mathrm{L}}$ Labeled as average $\mathrm{BCF}$ for exposures of unsealed earthworms in soil at $\mathrm{pH} 6.4$ by Heggelund et al. $^{11}$

(Figure S5). These results were used to calculate the steady state BAFs of Table 2.

As expected, the BAF values calculated from the ${ }^{68} \mathrm{Zn}-\mathrm{E}$ tissue concentrations measured at $72 \mathrm{~h}\left(\mathrm{BAF}_{\text {soil-72h }} \mathrm{BAF}_{\text {water-72h }}\right)$ are lower than the respective values determined from the modeled steady state tissue burdens $\left(\mathrm{BAF}_{\text {soil-ss }}, \mathrm{BAF}_{\text {water-ss }}\right)$, and these differences are larger for unsealed earthworms with combined dermal and oral uptake of ${ }^{68} \mathrm{Zn}-\mathrm{E}$ (Table 2). Furthermore, all BAF data obtained for exposures with ${ }^{68} \mathrm{ZnO}$ NP are either identical or remarkably similar to the results acquired for experiments with added dissolved ${ }^{6} \mathrm{Zn}$ (Table 2). Notably, the $\mathrm{BAF}_{\text {water }}$ results for the dermal-only uptake of sealed earthworms are also very similar to the $\mathrm{BAF}_{\text {soil }}$ data for dermal and oral uptake, using both the 72-h and the modeled steady state ${ }^{68} \mathrm{Zn}$-E tissue concentrations. For example, dermalonly uptake yields $\mathrm{BAF}_{\text {water-ss }} \approx 2.8$ and 3.7 , while dermal and oral uptake is associated with $\mathrm{BAF}_{\text {soil-ss }} \approx 3.4$ and 4.9 (Table 2).

\section{DISCUSSION}

4.1. Zinc Behavior in Soil. Care was taken to achieve a homogeneous distribution of added ${ }^{68} \mathrm{Zn}-\mathrm{E}$ in the test soils but this was not specifically tested. However, the data obtained for three soils indicate that a good distribution was achieved, although owing to the low levels of ${ }^{68} \mathrm{Zn}-\mathrm{E}$ used and the nature of soil, some minor heterogeneity (of \pm 20 to $30 \%$ ) is difficult to avoid (Table S5).

After the 2-day acclimatization period, the ${ }^{68} \mathrm{Zn}-\mathrm{E}$ concentrations in the two exposure systems were identical, within error, for both soils and pore waters (Table S5). After the 6-day exposure period, the ${ }^{68} \mathrm{Zn}$-E concentration of the pore water had increased for both treatments, whereby the end point concentration was $\sim 24 \%$ higher when dissolved ${ }^{68} \mathrm{Zn}$ was added (Table S5). This supports the suggestion that at these low soil concentrations the NPs underwent rapid dissolution during the acclimatization period and that the two forms of $\mathrm{Zn}$ display similar environmental behavior and partitioning, with comparable amounts binding to the available soil surfaces and entering the pore water phase.
These results can be compared to the study of Heggelund et al., ${ }^{11}$ where soils were dosed with $\mathrm{ZnO}$ NPs and $\mathrm{ZnCl}_{2}$ at much higher $\mathrm{Zn}$ concentrations of $238-2500 \mathrm{mg} \mathrm{kg}^{-1}$ (Figure S1). After acclimatization for 10 days, these authors found that soils treated with $\mathrm{ZnCl}_{2}$ had pore water $\mathrm{Zn}$ concentrations that were 20-50-fold higher compared to equivalent soils dosed with $\mathrm{ZnO}$ NPs. The largest differences were hereby seen at high levels of $\mathrm{Zn}$ addition. The NPs used by these workers had a nominal particle size of $30 \mathrm{~nm}$, larger than the particles used here, and therefore dissolution rates are expected to be lower. ${ }^{30}$ However, the larger particle size is unlikely to be primarily responsible for the different $\mathrm{Zn}$ pore water concentrations. Rather, the distinct $\mathrm{Zn}$ partitioning observed by Heggelund et al. ${ }^{11}$ is most likely a consequence of the high $\mathrm{Zn}$ dosing levels that were employed and not characteristic of the $\mathrm{Zn}$ behavior observed at the lower, environmentally relevant, concentrations used here.

Furthermore, it was observed in previous studies that the treatment of soils with high concentrations of $\mathrm{ZnO}$ NPs or dissolved $\mathrm{Zn}$ can influence the soil $\mathrm{pH} .^{11,12}$ Such changes in $\mathrm{pH}$ will have an impact on soil toxicity, hence making it difficult to compare any effects and toxicity between the two metal forms, as the $\mathrm{pH}$ modulating effects differ between the NP and ionic forms of $\mathrm{Zn}$. In contrast, the low $\mathrm{Zn}$ dosing levels employed in this study will be buffered by the soil and are not expected to have any impact on soil chemistry.

4.2. Zinc Uptake and Accumulation. In this study, uptake of the two ${ }^{68} \mathrm{Zn}$-E forms by the earthworm L. rubellus yielded essentially indistinguishable results. However, accumulation of ${ }^{68} \mathrm{Zn}$-E in the unsealed worms leads to ${ }^{68} \mathrm{Zn}$-E tissue concentrations that are about a factor of 20 higher than in sealed specimens (Figure 1 and Table S5). This demonstrates that ${ }^{68} \mathrm{Zn}-\mathrm{E}$ from $\mathrm{ZnO}$ NPs is as bioavailable as the ionic form and that oral ingestion constitutes the major uptake pathway, while uptake through the body wall plays a minor but nonetheless significant role contributing about $5 \%$ of total uptake. The exposure of the earthworms in two sequential stages, whereby the second set of earthworms was added to the 
test soils $24 \mathrm{~h}$ after the first, was not associated with any identifiable change in the uptake of ${ }^{68} \mathrm{Zn}$-E. This implies that our sequential exposure approach is unlikely to have had any significant impact on the final results.

The similarity observed in the tissue accumulation and uptake kinetics for the two ${ }^{68} \mathrm{Zn}$-E forms is presumably related to the low dosing concentrations that were employed. In particular, the dissolution of ${ }^{68} \mathrm{ZnO} \mathrm{NPs}$ over the 2-day acclimatization period is likely to have produced exposure conditions and speciation similar to those established in soils treated with dissolved ${ }^{68} \mathrm{Zn}$. This conclusion is supported by the similarity of the ${ }^{68} \mathrm{Zn}-\mathrm{E}$ concentrations in the soil pore waters (Table S5 and Figure S2). Different behavior, however, is likely for studies where higher concentrations of $\mathrm{ZnO}$ NPs are employed, as dissolution will be limited when the pore water surrounding the NPs approaches or achieves local saturation. These findings may explain why Heggelund et al. ${ }^{11}$ and Hooper et al. ${ }^{10}$ observed higher $\mathrm{Zn}$ tissue concentrations and lower toxicity for earthworms when exposed to $\mathrm{ZnO}$ NPs in comparison to dissolved $\mathrm{Zn}$. These authors attributed their observations to the direct internalization of $\mathrm{ZnO}$ NPs by the organisms, which may later deliver nanospecific toxicity. However, in our study, the exposures to the two ${ }^{68} \mathrm{Zn}-\mathrm{E}$ forms yielded identical internal ${ }^{68} \mathrm{Zn}$-E concentrations. This suggests that there is a fundamental difference in the $\mathrm{Zn}$ uptake and excretion pathways and forms that are relevant when $\mathrm{ZnO}$ NPs are present at high and low levels in soils. In particular, this may reflect faster and more complete dissolution of the NPs within the soil at low concentrations, such that discrete particles are not available for uptake by organisms, whereas at high concentrations NPs may not undergo complete dissolution and so can be taken up directly.

Dermal uptake of metals from soils using sealed and unsealed L. rubellus was also investigated by Vijver et al. ${ }^{25}$ These authors used two contaminated soils with very high total $\mathrm{Zn}$ concentrations of 700 and $2000 \mathrm{mg} \mathrm{kg}^{-1}$ but the levels of soluble $\mathrm{Zn}$, of 66 and $96 \mathrm{ng} \mathrm{mL} \mathrm{L}^{-1}$, were comparable to the test soils employed here. Notably, the sealing of earthworm mouthparts only resulted in a 21 to $30 \%$ reduction of the $\mathrm{Zn}$ uptake by the earthworms, compared to the $95 \%$ reduction seen here. This indicates that the dominant uptake routes may be concentration dependent, with earthworms scavenging metals when ambient concentrations are low while they will attempt to regulate metal uptake when ambient levels are high. This is an interesting finding and highlights the need to conduct investigations at low and high levels to better understand concentration effects.

The BAF values reported by Heggelund et al. ${ }^{11}$ cannot be directly compared to the data determined here (Table 2), as our study focuses solely on the mass balance of the added ${ }^{68} \mathrm{Zn}$ $\mathrm{E}$, while the natural $\mathrm{Zn}$ background is ignored. The values calculated in this study are arguably more environmentally relevant and reflective of $\mathrm{Zn}$ deficient worms scavenging for the metal rather than worms, which are regulating an excess, as only the added ${ }^{68} \mathrm{Zn}-\mathrm{E}$ is considered and this was dosed at a low concentration. The BAFs of 0.48 and 0.39 reported by Heggelund et al. ${ }^{11}$ for exposures with $\mathrm{ZnO} \mathrm{NP}$ and dissolved $\mathrm{Zn}$, respectively, are much lower than our results of 3.40 and 4.86 for equivalent experiments (Table 2). This is consistent with other studies, which show that accumulation factors decrease at higher external $\mathrm{Zn}$ levels. This is explained by uptake being limited at higher exposure concentrations when saturation and/or toxic levels are reached. ${ }^{31,32}$ Heggelund et al. ${ }^{11}$ interpret BAFs of $<1$ as the earthworms being under stress at high $\mathrm{Zn}$ concentrations when they attempt to regulate excess metal uptake. Conversely, the values of $>1$ observed here indicate that at background levels of $\mathrm{Zn}$ in soil, the earthworms were indeed scavenging and retaining metals from the environment.

Notably, the data obtained here for $\mathrm{BAF}_{\text {water-ss }}$ (and $\mathrm{BAF}_{\text {water-72h }}$ ) by dermal-only uptake (sealed earthworms) are comparable to the $\mathrm{BAF}_{\text {soil-ss }}$ (and $\mathrm{BAF}_{\text {soil-72h }}$ ) values for the dermal and oral $\mathrm{Zn}$ accumulation of unsealed earthworms (Table 2). Most likely, this observation indicates that it is primarily $\mathrm{Zn}$ associated with pore water, which is taken up via the dermal accumulation route. This interpretation is supported by the observation that the $k_{1-\text { water }}$ values for dermal-only uptake of ${ }^{68} \mathrm{Zn}$-E are similar to the $k_{1}$ values determined for dermal and oral uptake from soil, whereby the former are about a factor of 2 larger (Table 1 ). The higher $k_{1-\text { water }}$ values may indicate that pore water associated ${ }^{68} \mathrm{Zn}-\mathrm{E}$ is more readily available for uptake than ${ }^{68} \mathrm{Zn}-\mathrm{E}$, which is adsorbed to soil surfaces and accumulated via the oral pathway.

The indistinguishable bioavailability and accumulation of $\mathrm{Zn}$ from $\mathrm{ZnO}$ NPs and dissolved $\mathrm{Zn}$ found in this study reinforces the suggestion of Hooper et al. ${ }^{10}$ that risk assessments can assume that the $\mathrm{Zn}$ introduced by $\mathrm{ZnO} \mathrm{NPs}$ is available in ionic form. However, our data does not unequivocally demonstrate in which form the ${ }^{68} \mathrm{Zn}-\mathrm{E}$ enters earthworm tissue when introduced into the soil as ${ }^{68} \mathrm{ZnO} \mathrm{NPs}$. If ${ }^{68} \mathrm{ZnO} \mathrm{NPs}$, or specific forms of ${ }^{68} \mathrm{Zn}$-E which are derived from the NPs, are internalized, this could possibly lead to nanospecific effects, which may only be evident in longer chronic or repeated exposures. Further work is hence necessary, which investigates (i) the chemical transformation experienced by different forms of $\mathrm{Zn}$ in relevant natural environments and (ii) the forms in which $\mathrm{Zn}$ is available to and taken up by earthworms.

In summary, many of the data presented here do not correlate well with the results of previous soil exposure studies, which employed higher $\mathrm{Zn}$ exposure levels. This is an important finding, as it indicates that concentration dependent effects must be taken into consideration in such investigations. In this study, the major pathway for uptake of $\mathrm{Zn}$ into earthworm tissue was oral ingestion of pore water and soil. Dermal uptake accounted for only 5\% of the total $\mathrm{Zn}$ uptake, primarily via absorption of dissolved $\mathrm{Zn}$ associated with pore water. Importantly, the results of this study demonstrate that the behavior and bioavailability of $\mathrm{ZnO}$ NPs, when introduced at an environmentally relevant concentration, are indistinguishable from dissolved $\mathrm{Zn}$. This implies that nanoecotoxicology hazard studies which employ high exposure concentrations, may lead to conclusions, for example on element uptake forms and kinetics, that are not directly relevant for environmentally relevant scenarios. Thus, any nanospecific effects found at high exposure levels may indeed not be relevant for risk assessments. However, the determination of changes in NP speciation is technically challenging, as the detection limits of the X-ray based techniques that are employed for such studies are much higher in comparison to the isotope tracing methods used here.

\section{ASSOCIATED CONTENT}

\section{Supporting Information}

The Supporting Information is available free of charge on the ACS Publications website at DOI: 10.1021/acs.est.5b03413. 
Natural $\mathrm{Zn}$ concentrations and predicted environmental concentrations of $\mathrm{ZnO}$ NPs (Figure S1), details of the synthesis and characterization of the ${ }^{68} \mathrm{Zn}-\mathrm{E}$ forms, outline of the experimental protocol and sample timing (Table S1), images of earthworms with sealed mouthparts (Figure S2), sample preparation and chemical separation protocols (Table S2), isotope abundances and atomic weights of natural $\mathrm{Zn}$ and ${ }^{68} \mathrm{Zn}-\mathrm{E}$ (Table S3), experimental results for control samples (Table S4), summary of experimental results for exposed samples (Table S5), concentration of ${ }^{68} \mathrm{Zn}-\mathrm{E}$ in pore waters (Figure S3), concentration of natural $\mathrm{Zn}$ and ${ }^{68} \mathrm{Zn}-\mathrm{E}$ in exposed samples (Figure S4), and modeled uptake of ${ }^{68} \mathrm{Zn}-\mathrm{E}$ over a period of 30 days (Figure S5) (PDF)

\section{AUTHOR INFORMATION}

\section{Corresponding Author}

*E-mail: a.laycock10@imperial.ac.uk. Tel: +4420 75949983.

\section{Author Contributions}

A.L. and M.D.-O. are joint first authors. M.R. and C.S. are joint senior authors.

\section{Notes}

The authors declare no competing financial interest.

\section{ACKNOWLEDGMENTS}

Katharina Kreissig and Barry Coles of the Imperial College MAGIC Laboratories are thanked for technical assistance. Funding was provided by a UK Research Council studentship to A.L. and the joint U.S. EPA and U.K. NERC Research Program Grant RD-834557501-0. Dr. M. Diez-Ortiz was supported by a Marie Curie Intra-European Fellowship within the seventh European Community Framework Programme (call reference FP7-PEOPLE-2010-IEF, 273207 Nano-Ecotoxicity).

\section{REFERENCES}

(1) Auffan, M.; Rose, J.; Bottero, J. Y.; Lowry, G. V.; Jolivet, J. P.; Wiesner, M. R. Towards a definition of inorganic nanoparticles from an environmental, health and safety perspective. Nat. Nanotechnol. 2009, 4 (10), 634-641.

(2) Woodrow Wilson International Center for Scholars. The Nanotechnology Consumer Products Inventory. http://www. nanotechproject.org/cpi.

(3) Luoma, S. N. Silver Nanotechnologies and the Environment; The Project on Emerging Nanotechnologies Report 15: Woodrow Wilson International Center for Scholars: Washington, DC, 2008; http://mail. nanotechproject.org/publications/page2/.

(4) Gottschalk, F.; Sonderer, T.; Scholz, R. W.; Nowack, B. Modeled Environmental Concentrations of Engineered Nanomaterials ( $\mathrm{TiO} 2$, $\mathrm{ZnO}, \mathrm{Ag}, \mathrm{CNT}$, Fullerenes) for Different Regions. Environ. Sci. Technol. 2009, 43 (24), 9216-9222.

(5) Boxall, A.; Chaudhry, Q.; Sinclair, C.; Jones, A.; Aitken, R.; Jefferson, B.; Watts, C. Current and Future Predicted Environmental Exposure to Engineered Nanoparticles; Central Science Laboratory, Department of the Environment and Rural Affairs: London, U.K., 2007; http://randd.defra.gov.uk/Document.aspx?Document= CB01098 6270 FRP.pdf.

(6) Bian, S. W.; Mudunkotuwa, I. A.; Rupasinghe, T.; Grassian, V. H. Aggregation and Dissolution of $4 \mathrm{~nm} \mathrm{ZnO}$ Nanoparticles in Aqueous Environments: Influence of $\mathrm{pH}$, Ionic Strength, Size, and Adsorption of Humic Acid. Langmuir 2011, 27 (10), 6059-6068.

(7) Ma, R.; Levard, C.; Judy, J. D.; Unrine, J. M.; Durenkamp, M.; Martin, B.; Jefferson, B.; Lowry, G. V. Fate of Zinc Oxide and Silver
Nanoparticles in a Pilot Wastewater Treatment Plant and in Processed Biosolids. Environ. Sci. Technol. 2014, 48 (1), 104-112.

(8) Smith, D. B.; Cannon, W. F.; Woodruff, L. G.; Garrett, R. G.; Klassen, R.; Kilburn, J. E.; Horton, J. D.; King, H. D.; Goldhaber, M. B.; Morrison, J. M. Major- and Trace-Element Concentrations in Soils from Two Continental-Scale Transects of the United States and Canada; U.S. Department of the Interior, U.S. Geological Survey, 2005; http:// pubs.usgs.gov/of/2005/1253/.

(9) Spurgeon, D. J.; Rowland, P.; Ainsworth, G.; Rothery, P.; Long, S.; Black, H. I. J. Geographical and pedological drivers of distribution and risks to soil fauna of seven metals $(\mathrm{Cd}, \mathrm{Cu}, \mathrm{Cr}, \mathrm{Ni}, \mathrm{Pb}, \mathrm{V}$ and $\mathrm{Zn}$ ) in British soils. Environ. Pollut. 2008, 153 (2), 273-283.

(10) Hooper, H. L.; Jurkschat, K.; Morgan, A. J.; Bailey, J.; Lawlor, A. J.; Spurgeon, D. J.; Svendsen, C. Comparative chronic toxicity of nanoparticulate and ionic zinc to the earthworm Eisenia veneta in a soil matrix. Environ. Int. 2011, 37 (6), 1111-1117.

(11) Heggelund, L. R.; Diez-Ortiz, M.; Lofts, S.; Lahive, E.; Jurkschat, K.; Wojnarowicz, J.; Cedergreen, N.; Spurgeon, D.; Svendsen, C. Soil $\mathrm{pH}$ effects on the comparative toxicity of dissolved zinc, non-nano and nano $\mathrm{ZnO}$ to the earthworm Eisenia fetida. Nanotoxicology 2014, 8 (5), 559-572.

(12) Kool, P. L.; Ortiz, M. D.; van Gestel, C. A. M. Chronic toxicity of $\mathrm{ZnO}$ nanoparticles, non-nano $\mathrm{ZnO}$ and $\mathrm{ZnCl}_{2}$ to Folsomia candida (Collembola) in relation to bioavailability in soil. Environ. Pollut. 2011, 159 (10), 2713-2719.

(13) Hu, C. W.; Li, M.; Cui, Y. B.; Li, D. S.; Chen, J.; Yang, L. Y. Toxicological effects of $\mathrm{TiO} 2$ and $\mathrm{ZnO}$ nanoparticles in soil on earthworm Eisenia fetida. Soil Biol. Biochem. 2010, 42 (4), 586-591.

(14) Manzo, S.; Rocco, A.; Carotenuto, R.; Picione, F. D.; Miglietta, M. L.; Rametta, G.; Di Francia, G. Investigation of $\mathrm{ZnO}$ nanoparticles' ecotoxicological effects towards different soil organisms. Environ. Sci. Pollut. Res. 2011, 18 (5), 756-763.

(15) Ma, H.; Kabengi, N. J.; Bertsch, P. M.; Unrine, J. M.; Glenn, T. C.; Williams, P. L. Comparative phototoxicity of nanoparticulate and bulk $\mathrm{ZnO}$ to a free-living nematode Caenorhabditis elegans: The importance of illumination mode and primary particle size. Environ. Pollut. 2011, 159 (6), 1473-1480.

(16) Gong, A.; Ye, C. M.; Wang, X. J.; Lei, Z. F.; Liu, J. M. Dynamics and mechanism of ultraviolet photolysis of atrazine on soil surface. Pest Manage. Sci. 2001, 57 (4), 380-385.

(17) Laverack, M. S. The Physiology of Earthworms; Pergamon Press: Oxford, U.K., 1963.

(18) Handy, R. D.; Owen, R; Valsami-Jones, E. The ecotoxicology of nanoparticles and nanomaterials: current status, knowledge gaps, challenges, and future needs. Ecotoxicology 2008, 17 (5), 315-325.

(19) Nowack, B.; Baalousha, M.; Bornhoft, N.; Chaudhry, Q.; Cornelis, G.; Cotterill, J.; Gondikas, A.; Hassellov, M.; Lead, J.; Mitrano, D. M.; von der Kammer, F.; Wontner-Smith, T. Progress towards the validation of modeled environmental concentrations of engineered nanomaterials by analytical measurements. Environ. Sci.: Nano 2015, 2, 421.

(20) Larner, F.; Rehkämper, M. Evaluation of stable isotope tracing for $\mathrm{ZnO}$ nanomaterials - new constraints from high precision isotope analyses and modeling. Environ. Sci. Technol. 2012, 46 (7), 4149-58.

(21) Khan, F. R.; Laycock, A.; Dybowska, A.; Larner, F.; Smith, B. D.; Rainbow, P. S.; Luoma, S. N.; Rehkämper, M.; Valsami-Jones, E. Stable Isotope Tracer To Determine Uptake and Efflux Dynamics of $\mathrm{ZnO}$ Nano- and Bulk Particles and Dissolved $\mathrm{Zn}$ to an Estuarine Snail. Environ. Sci. Technol. 2013, 47 (15), 8532-8539.

(22) Larner, F.; Dogra, Y.; Dybowska, A.; Fabrega, J.; Stolpe, B.; Bridgestock, L. J.; Goodhead, R.; Weiss, D. J.; Moger, J.; Lead, J. R.; Valsami-Jones, E.; Tyler, C. R.; Galloway, T. S.; Rehkämper, M. Tracing Bioavailability of $\mathrm{ZnO}$ Nanoparticles Using Stable Isotope Labeling. Environ. Sci. Technol. 2012, 46 (21), 12137-12145.

(23) Canadian Soil Quality Guidelines for the Protection of Environmental and Human Health: Ethylene Glycol; Canadian Council of Ministers of the Environment: Winnipeg, Canada, 1999; http://ceqgrcqe.ccme.ca/download/en/268. 
(24) Arnold, R. E.; Hodson, M. E. Effect of time and mode of depuration on tissue copper concentrations of the earthworms Eisenia andrei, Lumbricus rubellus and Lumbricus terrestris. Environ. Pollut. 2007, 148 (1), 21-30.

(25) Vijver, M. G.; Vink, J. P. M.; Miermans, C. J. H.; van Gestel, C. A. M. Oral sealing using glue: a new method to distinguish between intestinal and dermal uptake of metals in earthworms. Soil Biol. Biochem. 2003, 35 (1), 125-132.

(26) Arnold, T.; Schönbächler, M.; Rehkämper, M.; Dong, S.; Zhao, F. J.; Kirk, G. J.; Coles, B. J.; Weiss, D. J. Measurement of zinc stable isotope ratios in biogeochemical matrices by double-spike MC-ICPMS and determination of the isotope ratio pool available for plants from soil. Anal. Bioanal. Chem. 2010, 398 (7-8), 3115-25.

(27) Janssen, M. P. M.; Bruins, A.; Devries, T. H.; Vanstraalen, N. M. Comparison of Cadmium Kinetics in 4 Soil Arthropod Species. Arch. Environ. Contam. Toxicol. 1991, 20 (3), 305-312.

(28) OECD. Test No. 317: Bioaccumulation in Terrestrial Oligochaetes; OECD Publishing, 2010. DOI: $10.1787 / 2074577 x$

(29) Sokal, R. R.; Rohlf, F. J. Biometry: The Principles and Practice of Statistics in Biological Research, 3rd ed.; Freeman: New York, 1995.

(30) Mudunkotuwa, I. A.; Rupasinghe, T.; Wu, C. M.; Grassian, V. H. Dissolution of $\mathrm{ZnO}$ Nanoparticles at Circumneutral pH: A Study of Size Effects in the Presence and Absence of Citric Acid. Langmuir 2012, 28 (1), 396-403.

(31) Sample, B. E.; Schlekat, C.; Spurgeon, D. J.; Menzie, C.; Rauscher, J.; Adams, B. Recommendations to Improve Wildlife Exposure Estimation for Development of Soil Screening and Cleanup Values. Integr. Environ. Assess. Manage. 2014, 10 (3), 372-387.

(32) Spurgeon, D. J.; Hopkin, S. P. Risk assessment of the threat of secondary poisoning by metals to predators of earthworms in the vicinity of a primary smelting works. Sci. Total Environ. 1996, 187 (3), 167-183. 